\title{
The educational impact of implementation the education through adventure discipline in physical education and sports academic curriculum
}

\author{
Badau Dana \\ Department of Human Movement Sciences, Faculty of Medicine, \\ University of Medicine and Pharmacy of Targu Mures, Romania
}

\begin{abstract}
The inclusion in the curriculum for students of physical education specialization in Romania of a new disciplineEducation through adventure (EA) falls within the current trends of practicing physical activities and modernization of the European curriculum. The purpose of the study aims at assessing the educational level of implementation of EA discipline within the academic curriculum of physical education and sport specialization.

Purpose: $\quad$ Study through the survey method based on a questionnaire concerning the assessment of the educational impact of implementing the EA disciplines.

Material: $\quad 72$ students from physical education, University of Medicine and Pharmacy Targu Mures. The questionnaire on the assessment of the educational impact of implementing the EA discipline included 15 items with Linckert responses. Statistically processed with SPPS 20: Cronbach's alpha, effect size, the percentage of individual qualifications, the arithmetic mean, the standard deviation, t-test.

Results: $\quad$ The 15-item questionnaire had a Cronbach reliability scores .792 . We identified five patterns that emerged explaining more than $60.2 \%$ of the variance. $54.82 \%$ consider relevant the educational discipline with maximum response, effect size of each $\geq .683$ items, the results are statistically significant for all items, $p<0.05$. The study results reveal the major educational impact of EA discipline content, being considered by students as it follows: attractive, useful, effective with innovative relevance in the professional training.

Conclusions: We recommend the conduct of future studies of impact assessment of EA specific activities on students' motor abilities.

Keywords: curriculum, theoretical content, practical activities, adventure education, physical education.
\end{abstract}

\section{Introduction}

The improvement of the educational and academic training must aim at adjusting to the international standards and curricular modernization trend. Increasing the competitiveness of academic physical education (PE) can be achieved by implementing within the curricula of some innovative disciplines allowing the acquisition of additional professional knowledge and skills in accordance with the modern requirements and the expansion of practicing forms of physical activities.

The academic physical education curriculum requires the diversification of activities creatively in accordance with: the specific objectives, the academic functions, the students' preferences and the trends in specific areas [1]. The current trends in education have direct implications for the physical education curriculum [2]

A physical harmony creates the base of a higher intellectual yield and can become the foundation of a positive behavior for the individual in society [3].

Analyzing the curricular content situation in the European countries we have found that in many countries there are study programs for the specialization in recreational activities that also include disciplines containing outdoor recreational activities and adventure education. In Romania, in the field of physical education complying with the Romanian Agency for Quality Assurance in Higher Education (ARACIS) standards [4] there are 3 specializations: physical education and sports; sport and motor performance; physiotherapy and special motricity and the standards do not provide within the "Training disciplines and specializations for the bachelor's degree” any discipline specialized on education through

(C) Badau Dana, 2017

doi:10.15561/20755279.2017.0302 adventure.

In the latter of the $20^{\text {th }}$ century, many who used adventure activity for educational proposes used the terms experiential education and adventure education synonymously [5].

Adventure education focuses on growth and development through activity based on experiential education principles. Adventure education improves motor and psychical capacities by exploring real circumstances.

Previous research on the implementation of EA specific activities showed significant improvements of psychological issues [6-7] and the educational components [8-13].

The discipline Education through adventure includes a synthesis of interdisciplinary and trans-disciplinary knowledge concerning history, psychology, education, ecology, geography, philosophy, culture [12, 14-17].

Adventure education has many positive outcomes. A meta-analysis of studies identified forty major adventure education outcomes, grouped into the following six categories: leadership, self-concept, academic, personality, interpersonal, and adventuresomeness [18]. Adventure education has many positive outcomes. A meta-analysis of studies Identified forty major adventure education outcomes, grouped into the following six categories : leadership, self-concept, academic, personality, interpersonal, and adventuresomeness [18].

The main skills specific to the organization and to conduct activities of adventure education and outdoor education are of the following type: technical, safety, organizational, instructional, facilitation, flexible leadership experience-based judgment, problem-solving, decision-making, effective communication, professional ethics [19]. 
We believe that in addition to the skills acquired through the educational adventure activities, participants also acquire some knowledge and skills such as: kinetic, technical, psychological, geographical, artistic and cultural.

According to specialists the content of the academic curriculum needs to be diversified by using some innovative and attractive varied environments (terrestrial, acquatic and aerial, indoor, outdoor) and some modern methods and technologies which will lead to students' improvement: motor and technical training skills, theoretical and professional knowledge , of the functional capacity etc. [1, 3, 20-22].

\section{Purpose and hypothesis}

The faculties and the study curricula in the field of physical education have the role to contribute to the professional training of future physical education teachers in line with the specific current and modern trends.

The aim of our study was to assess the formative and educational level of implementation of a new discipline education through adventure within the curriculum of physical education and sports specialization at the University of Medicine and Pharmacy in Targu Mures.

The hypothesis of the study started from the assumption that the implementation of an innovative adventure education discipline, will have the educational and formative relevance on students from physical education and sports specialization and will contribute to acquiring new knowledge and creating specific professional skills.

As a result of the increasing impact of recreational activities such as adventure education and the extension of facilities by increasing the number of adventure parks in Romania, we have designed and implemented to students in physical education and sports specialization a new discipline Education through Adventure (EA) with mandatory nature, provided for the third year of study, with a total of 28 classes of theory and 28 classes of practical works. The education through adventure discipline was included in the $5 \%$ stipulated within ARACIS standards that allow the inclusion in the curriculum of new subjects at the university's option.

The topical content of the theoretical courses of Education through Adventure:

1. Adventure education - experiential education: concepts, features, principles;

2. Adventure education - means, elements;

3. Interrelation: education through adventure, experiential education and adventure learning;

4. Indoor adventure education - forms of organization and practice;

5. Adventure education in adventure parks - forms of organization and practice;

6. Adventure education through mountain and off road activities - forms of organization and practice;

7. Urban adventure education - forms of organization and practice;

8. Aquatic adventure education - forms of organization and practice;

9. Mountaineering tourism- general aspects, forms of organization and characteristics;

10. Guidance Techniques on the map and complementary;

11. Planning and preparing a mountain road itinerary and behavior during trips;

12. Behavior in adventure and tourism activities;

13. Specific equipment to adventure activities;

14. Survival and rescue techniques.

The content of practical work lessons of Educational adventure discipline:

- $\quad$ Lesson 1-3. Organization and conduct of adventure education activities;

- $\quad$ Lesson 4-6. Trails and adventure activities - indoor;

- $\quad$ Lesson 7. Team building exercises during adventure education lessons;

- Lesson 8-12. Specific activities of adventure education -outdoor;

- $\quad$ Lesson 13. Survival techniques;

- Lesson 14. Practical and methodical assessment.

We present below three examples of practical and methodical programs provided within the outdoor practical works carried out in a modular system (merged in 3 days):

1. Photo Trip Town Adventure: moderate effort; it is for people with a basic level of fitness and good health. The itinerary may take place in Brasov 5-6 $\mathrm{km}$. The aim of this adventure tour is to discover the main monuments of our town by walking and to made photos and to take information about them. Every participant will receive one map of the town and a paper with the main monuments, which need to be discovered and photographed. Evaluation: total time will be measured and turned into points. After the trip every group of 3-4 persons will make one presentation about what they have seen and what they have learnt.

2. Park Aventura Brasov Challenge: efort moderate/high according to the chosen tour, a high level of fitness. Every group of 3-4 persons has to pass three routes with different difficulties. Evaluation: total time will be measured and turned into points.

3. 7 Stairs Canyon Adventure: Description: The first part of the route means walking $3.1 \mathrm{~km}$ trough forest, then climbing the canyon. The way back will be covered by help of the flying fox ( $2.5 \mathrm{~km}$ with 21 parts) Along this route there will be placed some check-points, where the participants will have to fulfil some specific tasks. Evaluation: total time will be measured and turned into points. Extra points will be awarded for the fulfilment of the check-point tasks.

\section{Material and method}

Participants: The study comprised 72 students from physical education and sports specialization from the University of Medicine and Pharmacy Targu Mures, 58 boys $(80.5 \%)$ and 14 girls $(19.5 \%)$ with the average age 21.84. All the participants in this study were volunteers.

Procedure: The research was carried out between 
October 2015 - January 2017. The assessment targeted a survey based on a questionnaire concerning the degree of satisfaction and the educational impact of the implementation of adventure education discipline. The questionnaire contains 15 items with Linckert responses (5), 1 representing the minimum and 5 the maximum level of appreciation. The questionnaires were developed with the help of Google Form and the students were directly provided with them to the end of the course.

Statistical analyses

The resulting data were statistically processed with SPSS 20.

To assess the reliability or the internal consistency of the questionnaire it was calculated Cronbach's alpha statistic index. To assess the relevance and the effect size for each group of students were calculated the number and the percentage of subjects in relation to the maximal responses (5) for 4 grade and 3 on each item (Table 1). The statistical analysis included: the arithmetic mean, the standard deviation, the mean deviation error, the student t-test, the significance threshold $p$, for $p<.05$ and the effect size d (Table 2). Effect size is just a more commonly used as effect size measure, used in meta-analyses and summarizing strength of bivariate relationship [24].

We used to identify the important factors the Rotation Method: Varimax with Kaiser Normalization ,we took into account all the 15 items of the questionnaire. After identifying the relevant factors, the next step was to rename them according to the most relevant results to each factor (Table 3). Only items which had the positive values of higher than- 0.4 and 0.4 on one factor contributed directly to this pattern and were considered after renaming the factor. A high score of the items for a pattern indicated a high educational relevance.

\section{Results}

The average number of the subjects that rated the assessment questionnaire of the educational impact of EA

Table 1 .The statistical analysis of responses weight according to Linckert scale (5) on each item on the questionnaire assessing the educational impact of implementing EA discipline

\begin{tabular}{|c|c|c|c|}
\hline \multirow{2}{*}{ Items } & \multicolumn{3}{|c|}{ Responses weight $\mathbf{n}(\%)$} \\
\hline & 5 points & 4 points & 3 points \\
\hline Item 1. How innovative is EA discipline? & $32(44.4 \%)$ & $30(41.7 \%)$ & $10(13.9 \%)$ \\
\hline $\begin{array}{l}\text { Item 2. How do you appreciate the complexity of the curriculur } \\
\text { theoretical topics included in EA discipline sheet? }\end{array}$ & $32(44.4 \%)$ & $28(38.9 \%)$ & $12(16.7 \%)$ \\
\hline $\begin{array}{l}\text { Item } 3 . \text { How do you rate the educational relevance of theoretical } \\
\text { concepts specific to EA ? }\end{array}$ & $30(41.7 \%)$ & $35(48.6 \%)$ & $7(9.7 \%)$ \\
\hline $\begin{array}{l}\text { Item } 4 . \text { How do you rate the educational relevance of } 7 \text { Stairs } \\
\text { Canyon Challenge program? }\end{array}$ & $40(55.6 \%)$ & $24(33.3 \%)$ & $8(11.1 \%)$ \\
\hline $\begin{array}{l}\text { Item } 5 . \text { How do you rate the educational relevance of Brasov } \\
\text { Adventure Park program?? }\end{array}$ & $43(59.7 \%)$ & $22(30.6 \%)$ & $7(9.7 \%)$ \\
\hline $\begin{array}{l}\text { Item } 6 . \text { How do you rate the educational relevance of Photo } \\
\text { Adventure Trip program? }\end{array}$ & $36(50 \%)$ & $35(48.6 \%)$ & $1(1.4 \%)$ \\
\hline $\begin{array}{l}\text { Item 7. How do you assess the attractiveness of the programs } \\
\text { included in EA discipline? }\end{array}$ & $43(59.7 \%)$ & $25(34.7 \%)$ & $4(5.6 \%)$ \\
\hline $\begin{array}{l}\text { Item } 8 . \text { How do you assess the complexity of the practical work } \\
\text { topics included in the discipline sheet? }\end{array}$ & 36 (50\%) & $33(45.8 \%)$ & $3(4.2 \%)$ \\
\hline $\begin{array}{l}\text { Item } 9 . \text { How do you rate the educational relevance of the practical } \\
\text { module of survival techniques? }\end{array}$ & 46 (63.9\%) & $16(22.2 \%)$ & $10(13.9 \%)$ \\
\hline Item 10. How do you rate the assessment method of EA discipline? & $46(63.9 \%)$ & $15(20.8 \%)$ & $11(18.3 \%)$ \\
\hline $\begin{array}{l}\text { Item } 11 . \text { How do you rate the formative impact on the motor } \\
\text { ability of the programs included in the discipline? }\end{array}$ & $42(58.3 \%)$ & $22(30.6)$ & $8(11.1 \%)$ \\
\hline $\begin{array}{l}\text { Item } 12 . \text { How do you assess the collaboration and the mutual } \\
\text { aspects in order to accomplish specific tasks within the programs } \\
\text { included in EA discipline? }\end{array}$ & $46(63.9 \%)$ & $17(23.6 \%)$ & $9(12.5 \%)$ \\
\hline $\begin{array}{l}\text { Item 13. Do you consider that EA discipline implementing in the } \\
\text { curriculum is efficient in training teachers with physical education } \\
\text { specialization? }\end{array}$ & $36(50 \%)$ & $28(38.9 \%)$ & $8(11.1 \%)$ \\
\hline $\begin{array}{l}\text { Item 14. Rate the consistency between the discipline content and } \\
\text { the expansion trend of physical activities practicing forms }\end{array}$ & $43(59.7 \%)$ & $20(27.8 \%)$ & $9(12.5 \%)$ \\
\hline $\begin{array}{l}\text { Item 15. After the course completion will you continue to } \\
\text { implement in your future activity the accumulated knowledge and } \\
\text { experiences? }\end{array}$ & 41 (56.9\%) & $20(27.8 \%)$ & $11(15.3 \%)$ \\
\hline
\end{tabular}

$\mathrm{n}$ - number of Participants 
Table 2. Descriptive statistics for the results of the questionnaire assessing the educational impact of the Educational Adventure implementation

\begin{tabular}{|c|c|c|c|c|c|c|}
\hline Items & $\mathbf{x}$ & SD & SEM & $t$ (71 df) & d & $\mathbf{p}$ \\
\hline Item 1. How innovative is EA discipline? & 4.3056 & .70489 & .08307 & 51.829 & .985 & .000 \\
\hline $\begin{array}{l}\text { Item } 2 \text {. How do you appreciate the complexity of the } \\
\text { curriculum theoretical topics included in EA discipline sheet? }\end{array}$ & 4.2778 & .73585 & .08672 & 49.328 & .982 & .000 \\
\hline $\begin{array}{l}\text { Item } 3 . \text { How do you rate the educational relevance of } \\
\text { theoretical concepts specific to EA? }\end{array}$ & 4.319 & .646 & .08565 & 56.714 & .897 & .000 \\
\hline $\begin{array}{l}\text { Item } 4 \text {. How do you rate the educational relevance of } 7 \text { Stairs } \\
\text { Canyon Challenge program? }\end{array}$ & 4.4444 & .68974 & .08129 & 54.676 & .805 & .000 \\
\hline $\begin{array}{l}\text { Item } 5 . \text { How do you rate the educational relevance of Brasov } \\
\text { Adventure Park program?? }\end{array}$ & 4.5000 & .67135 & .07912 & 56.877 & .845 & .000 \\
\hline $\begin{array}{l}\text { Item 6. How do you rate the educational relevance of Photo } \\
\text { Adventure Trip program? }\end{array}$ & 4.4861 & .53056 & .06253 & 71.747 & .976 & .000 \\
\hline $\begin{array}{l}\text { Item } 7 . \text { How do you assess the attractiveness of the } \\
\text { programs included in EA discipline? }\end{array}$ & 4.5417 & .60369 & .07115 & 63.837 & .759 & .000 \\
\hline $\begin{array}{l}\text { Item } 8 \text {. How do you assess the complexity of the practical } \\
\text { work topics included in the discipline sheet? }\end{array}$ & 4.4583 & .57989 & .06834 & 65.237 & .934 & .000 \\
\hline $\begin{array}{l}\text { Item 9. How do you rate the educational relevance of the } \\
\text { practical module of survival techniques? }\end{array}$ & 4.5000 & .71158 & .08622 & 52.193 & .703 & .000 \\
\hline $\begin{array}{l}\text { Item 10. How do you rate the assessment method of EA } \\
\text { discipline? }\end{array}$ & 4.4861 & .75046 & .08844 & 50.724 & .684 & .000 \\
\hline $\begin{array}{l}\text { Item } 11 . \text { How do you rate the formative impact on the motor } \\
\text { ability of the programs included in the discipline? }\end{array}$ & 4.4722 & .69144 & .08149 & 54.883 & .762 & .000 \\
\hline $\begin{array}{l}\text { Item } 12 . \text { How do you assess the collaboration and the mutual } \\
\text { aspects in order to accomplish specific tasks within the } \\
\text { programs included in EA discipline? }\end{array}$ & 4.5139 & .71193 & .08390 & 53.800 & .683 & .000 \\
\hline $\begin{array}{l}\text { Item 13. Do you consider that EA discipline implementing in } \\
\text { the curriculum is efficient in training teachers with physical } \\
\text { education specialization? }\end{array}$ & 4.3889 & .68290 & .08048 & 54.533 & .895 & .000 \\
\hline $\begin{array}{l}\text { Item } 14 . \text { Rate the consistency between the discipline } \\
\text { content and the expansion trend of physical activities } \\
\text { practicing forms ? }\end{array}$ & 4.4722 & .71152 & .08385 & 53.334 & .741 & .000 \\
\hline $\begin{array}{l}\text { Item } 15 . \text { After the course completion you will continue } \\
\text { to implement in your future activity the accumulated } \\
\text { knowledge and experiences? }\end{array}$ & 4.4167 & .74588 & .08790 & 50.245 & .782 & .000 \\
\hline
\end{tabular}

x- mean arithmetic; SD - standard deviation; SEM - Standard Error Mean; $d$ - effect size; $p$ - level of probability.

discipline implementation with maximum grade (5) were 32.45 students, representing $54.82 \%$; 4 grade - 24.66 students, representing $34.26 \%$ and grade $3-7.86$ students, representing 10.91\% (Table 1).

Statistical processing of the questionnaire for the sample of students highlighted the results statistically significant for $p<0.05$, the average value of the questionnaire was 4438, where the average minimum value was 4.278 and the average maximum value was 4.542.

A Principal Component Analysis (PCA) was conducted on 15 items with orthogonal rotation (varimax). The Keiser-Meyer-Olkin measure verified the sampling adequacy for analysis, $\mathrm{KMO}=0.651$, which are above Keiser's criteria ( $>0.5)$. Bartlett's test of sphericity $\chi^{2}(105)=207.22, \quad \mathrm{p}<0.001$, indicated that correlation between items were sufficiently large for PCA.

An initial analysis was run to obtain eigen values for each component in the data. Five components had eigen values over Keiser's criterion of 1 and in combination explained $60.2 \%$ of the variance. 
Table 3. Items Relevance for the 5 identified patterns - Rotated Component Matrix

\begin{tabular}{|c|c|c|c|c|c|}
\hline \multirow{2}{*}{ Items } & \multicolumn{5}{|c|}{ Components } \\
\hline & 1 & 2 & 3 & 4 & 5 \\
\hline Item 1. How innovative is EA discipline? & -.056 & .205 & -.001 & .745 & -.304 \\
\hline $\begin{array}{l}\text { Item 2. How do you appreciate the complexity of the curriculur } \\
\text { theoretical topics included in EA discipline sheet? }\end{array}$ & .239 & .624 & -.132 & -.093 & -.072 \\
\hline $\begin{array}{l}\text { Item } 3 . \text { How do you rate the educational relevance of theoretical } \\
\text { concepts specific to EA ? }\end{array}$ & .699 & .030 & .084 & -.084 & .080 \\
\hline $\begin{array}{l}\text { Item } 4 . \text { How do you rate the educational relevance of } 7 \text { Stairs Canyon } \\
\text { Challenge program? }\end{array}$ & .067 & -.144 & .043 & -.111 & .780 \\
\hline $\begin{array}{l}\text { Item } 5 . \text { How do you rate the educational relevance of Brasov Adventure } \\
\text { Park program?? }\end{array}$ & .166 & -.231 & .010 & .786 & 199 \\
\hline $\begin{array}{l}\text { Item } 6 . \text { How do you rate the educational relevance of Photo Adventure } \\
\text { Trip program? }\end{array}$ & .101 & .039 & .846 & -.011 & .133 \\
\hline $\begin{array}{l}\text { Item 7. How do you assess the attractiveness of the programs included } \\
\text { in EA discipline? }\end{array}$ & .817 & .108 & .038 & .000 & .072 \\
\hline $\begin{array}{l}\text { Item } 8 . \text { How do you assess the complexity of the practical work topics } \\
\text { included in the discipline sheet? }\end{array}$ & .608 & .111 & .353 & .351 & -.216 \\
\hline $\begin{array}{l}\text { Item 9. How do you rate the educational relevance of the practical } \\
\text { module of survival techniques? }\end{array}$ & .191 & .232 & .615 & -.082 & -.036 \\
\hline Item 10. How do you rate the assessment method of EA discipline? & .221 & .419 & .277 & .005 & .468 \\
\hline $\begin{array}{l}\text { Item } 11 . \text { How do you rate the formative impact on the motor ability of } \\
\text { the programs included in the discipline? }\end{array}$ & -.044 & .488 & .068 & .344 & .570 \\
\hline $\begin{array}{l}\text { Item } 12 \text {. How do you assess the collaboration and the mutual aspects } \\
\text { in order to accomplish specific tasks within the programs included in EA } \\
\text { discipline? }\end{array}$ & .325 & .584 & .249 & -.039 & .061 \\
\hline $\begin{array}{l}\text { Item 13. Do you consider that EA discipline implementing in the } \\
\text { curriculum is efficient in training teachers with physical education } \\
\text { specialization? }\end{array}$ & .542 & .424 & -.196 & .227 & .192 \\
\hline $\begin{array}{l}\text { Item 14. Rate the consistency between the discipline content and the } \\
\text { expansion trend of physical activities practising forms ? }\end{array}$ & -.193 & .704 & .355 & .084 & -.056 \\
\hline $\begin{array}{l}\text { Item } 15 . \text { After the course completion you will continue to implement in } \\
\text { your future activity the accumulated knowledge and experiences? }\end{array}$ & -.150 & -.044 & .485 & .350 & .116 \\
\hline Eigen values & 2.173 & 2018 & 1.78 & 1634 & 1,424 \\
\hline Variance explained \% & $14.0 \%$ & $13.45 \%$ & $11.92 \%$ & 10.98 & 9.49 \\
\hline
\end{tabular}

Extraction Method: Principal Component Analysis. Rotation Method: Varimax with Kaiser Normalization a. Rotation converged in 11 iterations. The primary factor loadings are in bold font.

\section{Discussions}

The Cronbach's alpha coefficient for 15 items is .792, valid number 72, suggesting that the items have high internal consistency.

The pooled results (Table 1) highlight superior percentages obtained to all items for the maximum response 5. For grade 5, the maximum percentage was $63.9 \%$ accounting for items concerning the educational relevance of : the practical module of survival techniques (item 9), the assessment method for EA discipline (item 10 ), the aspects of cooperation and mutual support to accomplish specific tasks for EA discipline (item 12), and the minimum percentage value was $41.7 \%$ being registered to item 3 concerning the educational relevance of the EA specific theoretical concepts. For grade 4, the maximum percentage value was $48.6 \%$ obtained to Item 6 concerning the relevance of the educational program Photo Trip Adventure and the minimum percentage value was $20.8 \%$ to item 10 concerning the assessment method for EA discipline . For grade 3, the maximum value was $18.3 \%$ obtained at Item 10 concerning the assessment method for EA discipline and the minimum percentage value was $1.4 \%$ to Item 6 concerning the educational relevance of the program Photo Trip Adventure. It is relevant to mention that no student has awarded the grades 1 or 2 .

According to the assessment scale of Cohen's effect size [23], for $\mathrm{p}<0.05$ (Table 2) the study highlights a big effect $\geq .80$ in the following items: the complexity of theoretical curricular themes included in EA sheet discipline, the complexity of theoretical curricular themes included in EA discipline sheet , the educational relevance of the theoretical concepts specific to EA, the educational relevance of Challenge 7 Stairs Canyon program, the educational relevance of Adventure Park Brasov, the educational relevance of Photo Trip Adventure program, 
the complexity of the practical works topics included in the sheet discipline, the implementation efficiency of EA discipline within the curriculum of training physical education teachers.

An average level of the effect size (values between .50 and .80 values) was registered in the case of the following items: the attractiveness of the programs included in EA discipline, the educational relevance of the practical module of survival techniques, the assessment method in EA discipline, the formative impact on the motor ability of the programs included in the discipline, the cooperation and mutual help aspects in order to accomplish the specific tasks within the programs included in EA discipline, the consistency between the content of the discipline and the expansion trend of practicing forms of physical activities, the further implementation in the future activity of the gained knowledge and experiences.

It is relevant that there were no values of the effect size smaller than .683 .

After processing the results, five patterns were obtained (Table 3) that were renamed according to the most relevant value obtained on the vertical so: F1- The attractiveness of EA programs; F2 - The consistency between the discipline content and the trend; F3 - Photo Trip Adventure; -Adventure Park Brasov F4, F5 Challenge 7 Stairs Canyon.

The analysis of the survey results for each of the 5 patterns highlighted that there are no negative values inferior to -0.40 for the group of students with physical education and sports specialization.

For the first pattern which accumulates $14 \%$ of the variant called the Attractiveness of EA programs, they were identified as relevant the following questions of the questionnaire: the educational relevance of the theoretical concepts specific to EA, the attractiveness of the programs included in EA discipline , the complexity of the practical works topics included in the discipline, the efficiency of EA implementation within the training curricula of the physical education teachers.

The second pattern called The Consistency between the discipline content and trend include important information regarding the complexity of the theoretical curricular themes included in EA discipline sheet, the assessment method in EA discipline, the formative impact on the motor ability of the programs included in the discipline , the cooperation and mutual help aspects in order to accomplish the specific tasks within the programs included in EA discipline, the efficiency of EA implementation within the training curricula of the physical education teachers, the consistency between the content of the discipline and the expansion trend of practising forms of physical activities.

The third pattern called Photo Adventure Trip includes great relevance of information regarding: the educational relevance of the Photo Adventure Trip program, the educational relevance of the practical module of survival techniques, the further implementation in the future work of the gained knowledge and experiences.

The fourth pattern called Adventure Park Brasov comprised $10.98 \%$ of variance targeting relevant information about: the innovative degree of EA discipline, the educational relevance of Brasov Adventure Park program, the assessment method of EA discipline .

The fifth pattern called Challenge 7 Stairs Canyon includes assessments of the following information: the educational relevance of 7 Stairs Canyon Challenge program, the formative impact on the motor ability of the programs included in the discipline.

The education should be changes. This change is produced under the impact of the pedagogical tradition, that of the contemporary word problem and the future being know that "future order to the present" [24]. The curriculum means a path to cover, organizing and triggering learning, transforming the student in an adaptive manner [25].

Evaluation is a way for adventure programs to document their worth by providing evidence of their contributions to society, or other desirable outcomes the program has achieved [26].

Searching of ways to improve students' health, development of some kinds of sports, creation of favorable conditions for formation of youth's positive attitude to healthy life style, training of professional-applied skills of future specialists and other can be considered to be the main purpose of such researches [27].

Our studies have shown that by running adventure education programs students were perceived as more competent in the social and professional environments, aiming at the intra-professional, ethical, and theoretical aspects of their professions[14.28].

Modernizing the learning process by combining different ways and contexts is based on the exploration and experimentation of sporting and recreational activities of adventure type that promote the growth of functional mobility and the intellectual potential of students from the Faculty of Physical Education and Sports [14].

\section{Conclusions}

The study outcomes reveal the major impact of the Educational Adventure content on the educational and satisfaction aspects to students in physical education and sports specialization.

The Education through Adventure course content is considered by some of the students attractive, useful, efficient with innovative relevance for the training of the future teachers of physical education and sports.

The expanding forms of practising recreational physical activities being in line with the modern trends in the field ,require the updating of the academic curricula to students with physical education and sports specialization, which will help to improve the professional competences and the Education through Adventure discipline represents a viable alternative in this regard, which has been highly outlined by the results of our study.

\section{Conflict of Interests}

The author declares that there is no conflict of interests. 


\section{References}

1. Badau A. Aquagym. Theory and methodology, Transilvania University Publish House; 2016.

2. De Luke K, Melograno V. Developing the Physical Education Curriculum: an Achievement-based Approach, Human Kinetics; 2004.

3. Badau A. The level evaluation of motric qualities at medicine students. The Annals of "Dunarea De Jos" University of Galati, Fascicle XV. 2016;1:20-5.

4. Standardele Specifice pentru Domeniul Educatie Fizică şi Sport [Specific Standards for Physical Education and Sports]. [Internet]. 2017 [updated 2017 Feb 10; cited 2017 Feb 10]. Available from http://www.aracis.ro/uploads/ media/standarde_specifice_C08.pdf (in Romanian)

5. De Clayne RJ, Guthrie S. Outdoor Recreation in America, Human Kinetics; 2006.

6. Harper NJ, Webster AL. Higher learning: impacts of a highaltitude adventure-based field school on college student development. Journal of Adventure Education and Outdoor Learning, 2016; 17(1):67-81. doi:10.1080/14729679.2016.1 217782

7. Sheard M, Golby J. The Efficacy of an Outdoor Adventure Education Curriculum on Selected Aspects of Positive Psychological Development, Jounal of Experiential Education, 2006; 29(2):187-209. doi: $10.1177 / 105382590602900208$

8. Sutherland S, Legge M. The Possibilities of "Doing” Outdoor and/or Adventure Education in Physical Education/Teacher Education. Journal of Teaching in Physical Education. 2016;35(4):299-312. doi:10.1123/jtpe.2016-0161

9. Timken GL, McNamee J. New Perspectives for Teaching Physical Education: Preservice Teachers' Reflections on Outdoor and Adventure Education, Journal of Teaching in Physical Education. 2012;31(1):21-38. doi:10.1123/ jtpe.31.1.21

10.Badau A, Badau D. Aqua-pullpush-gym. An novative method of gymnastic in water. Transilvania Univerity Publish House; 2011.

11.Doering A. Adventure Learning: situating learning in an authentic context. Innovate: Journal of online Education. 2007;3(6):20-25.

12.Plaut L. Degree-Granting Programs in Adventure Education: Added Value? Journal of Experiential Education, 2016;24(3):136-140, doi:10.1177/105382590102400303

13. Veletsianos G, Doering A. Long-term student experiences in a hybrid, open-ended and problem based Adventure Learning program. Australian Journal of Educational Technology, 2010;26(2):280-96. doi:10.14742/ajet.1096

14.Badau D. Interrelation triangle: Adventure education learning adventure - experiential education, Proceedings of the International Scientific Conference Effects of Physical Activity Application to Anthropological Status with Children,
Youth and Adults, 2014. 11-12 Dec. Belgrade, Serbia. Beograd: 3D+; 2014. P.22-3.

15.Stremba B. Teaching Adventure Education Theory: Best Practice. Human Kinetics; 2009.

16.Karppinen SJA. Outdoor adventure education in a formal education curriculum in Finland: action research application, Journal of Adventure Education and Outdoor Learning. 2012;12(1):41-62. doi:10.1080/14729679.2011.569186

17.Norton CN, Hsieh CM. Cultural bridging through shared adventure: cross-cultural perspectives on adventure therapy Journal of Adventure Education and Outdoor Learning. 2011;11(2):173-81. doi:10.1080/14729679.2011.633390

18.Hattie J, Marsh H, Neill JT, Richards G. Adventure education and Outward Bound: Out-of class experiences that make a lasting difference. Review of Educational Research, 1997;67(1):43-8. doi:10.3102/00346543067001043

19.Priest S, Grass MA. Effective leadership in adventure programming. $2^{\text {nd }}$ ed. Champaingn IL Human Kinetics; 2005.

20.Kudryavtsev MD, Kopylov YA, Kuzmin VA, Ionova OM, Yermakova TS. Personality oriented system of strengthening of students' physical, psychic and socialmoral health. Physical education of students. 2016;3:43-52. doi:10.15561/20755279.2016.0306

21.Badau D, Badau A. The Influence of various types of water gymnastics upon the exercise capacity. International Journal of Science Culture and Sport (IntJSCS), 2015;3(4):94-102. doi:10.14486/IntJSCS463

22.Grosu VT, Rusu AC, Grosu EF. Neurolinguistic programming techniques in sports training for enhancing performance capacity. Palestrica of the third millennium - Civilization and Sport. 2010;14(3):212-8.

23.Cohen J. A power primer. Psychological Bulletin, 1992:155159. doi:10.1037/0033-2909.112.1.155

24.Ion-Ene M, Neofit A. The early education in the educational new context, Univeristaria. 2016;18:54-9.

25.Iconomescu TM, Alexe DI. Differences and similarities in curriculum and assessment in physical education in Eastern European States. Ovidius University Annals, Series Physical Education and Sport/Science, Movement and Health. 2015;15(1):41-6.

26.Attarian A. Trends in Outdoor Adventure Education. The Journal of Experiential Education. 2001;24(3):141-9. doi:10.1177/105382590102400304

27.Iermakov SS, Cieślicka M, Muszkieta R. Physical culture in life of Eastern European region students: modern state and prospects of development. Physical education of students. 2015;6:16-30. doi:10.15561/20755279.2015.0603

28. Marinho A, Mari dos Santos P, Manfroi MN, Figueiredo JP, Zeilmann Brasil B. Reflections about outdoor adventure sports and professional competencies of physical education students. Journal of Adventure Education And Outdoor Learning. 2017;17(1):38-54. doi:10.1080/14729679.2016.1 218781 
Information about the author:

Dana Badau; Prof., PhD. Hab.; http://orcid.org/0000-0002-1881-3531; danabadau.brasov@gmail.com; Department of Human Movements Science, University of Medicine and Pharmacy of Tirgu Mures. President of Romanian Federation Sport for all; Strada Gheorghe Marinescu 38, Târgu Mureș 540139, Romania.

Cite this article as: Badau D. The educational impact of implementation the education through adventure discipline in physical education and sports academic curriculum. Physical education of students, 2017;21(3):108-115. doi:10.15561/20755279.2017.0302

The electronic version of this article is the complete one and can be found online at: http://www.sportedu.org.ua/index.php/PES/issue/archive

This is an Open Access article distributed under the terms of the Creative Commons Attribution License, which permits unrestricted use, distribution, and reproduction in any medium, provided the original work is properly cited (http://creativecommons.org/licenses/by/4.0/deed.en).

Received: 05.03.2017

Accepted: 15.03.2017; Published: 10.05.2017 